\title{
Observações sobre a exposição de Per-Erik Nilsson
}

O depoimento do Sr. Nilsson sugere, desde logo, uma ampla reflexão a respeito da eficácia dos controles institucionais sobre o desempenho da Administração Pública, tal como eles foram concebidos e são implementados no Brasil.

Em segundo lugar, a exposição do Sr. Niłsson indica a estreita correlação que existe entre a qualidade desses controles e o conteúdo democrático do próprio sistema político-administrativo.

Em terceiro lugar, a descrição das atribuições do Ombudsman induz naturalmente à comparação, ainda que sucinta, com o trabalho que vem sendo desenvolvido no Brasil, ao longo dos últimos 4 anos, pelo Ministério da Desburocratização.

Quanto ao conceito de controle, está claro que o Ombudsman busca primordialmente o controle finalístico do ato administrativo, ou seja, a sua qualidade intrínseca, enquanto no Brasil, por força da nossa tradição formalista, o controle está voltado para a legalidade do ato administrativo. Aqu। prepondera o controle a posteriori exerci- do externamente pelo Congresso e internamente através da supervisão ministerial

Quanto à forma de implementação do controle, há que se ter em conta uma diferença fundamental entre os dois sistemas administrativos. Adotando a Suécia o regime parlamentarista de governo, existe uma clara separação entre o núcleo central da Administração - o Ministério - e os órgãos admínistrativos exclusivamente de execução. Apenas estes são fiscalizados pelo Ombuds. man.

No Brasil, o Executivo forma um corpo único, não havendo, na prática, a nútida separação de atribuiçōes de governo e atribuiçōes de execução. O controle interno, realizado por meio de supervisão ministerial, padece pois de uma insuficiência básica. qual seja a de restringir-se ao controle "interna corporis" -. o que limita drasticamente a sua eficácia e abrangência.

Por outro lado, o controle externo repousa essencialmente nos Tribunais de Contas, cuja característica principal é o seu 
caráter formal, voltado apenas para a legalidade do ato administrativo.

Quanto à relação entre controle fiñalístico e democracia, ressalta da exposição do Sr. Nilsson o papel importantíssimo representado pelos meios de comunicação. ou seja, dos mecanismos não institucionais de controle, que dão cobertura ao trabalho do Ombudsman. Creio que, também no Brasil, estamos rapidamente verificando a relevância dos mecanismos informais de controle da sociedade sobre o desempenho administrativo do Estado.

Isto nos sugere a necessidade de buscar novas formas de controle, fora das categorias convencionais de controle adotadas no Brasil. Neste sentido, a experiência brasileira recente do Ministério da Desburocratização parece-me extremamente significativa. Tratase de uma ientativa de criação de um canal direto de comunicação entre os cidadãos e a máquina administrativa , contornando portanto o formalismo e o isolacionismo, que ainda presidem a relação entre o Estado e a sociedade.

O volume crescente de queixas e sugestões que chegam ao Ministério da Desburocratização revelam, por si só, a carência de canais desobstruidos, que evitem intermediações desnecessárias entre o Governo e os indivíduos.

Há algumas semelhanças marcantes enure as atribuições do Ombudsman e as do Ministro da Desburocratização:

10) garantir os direitos dos cidadãos perante o aparelho administrativo do Estado;

20) receber e investigar queixas apresentadas pelos cidadões e propor as mudança que se fizerem necessárias;

30) promover a revisão da legislação com o objetivo de melhorar a qualidade do desempenho da administração (no nosso caso, busca-se combater a centralização administrativa, o formalismo e os excessos burocráticos em geral, consubstanciados em uma legislação antiquada).

40) não podem anular os atos administrativos, se bem que ambos tenham o poder de denunciar desvios administrativos. 10 Ombudsman pode ainda recorrer diretamente ao Judiciário para punir os administradores faltososi. vulto:

Algumas diferenças são também de

19) O Ombudsman é vinculado ao Parlamento, enquanto o Ministro da Desburocratização întegra o Poder Executivo.

29) A estera de ação do Ombudsman é mais ampla, na medida em que abrange as administrações estaduais e municipais, além do próprio Poder Judiciário, inclusive a Suprema Corte.

30) O processo de escolha do Ombuds. man e as prerrogativas da função lhe asseguram, sem dúvida, um grau excepcional de independência. (Tendo um mandato de 4 anos, o Ombudsman só pode ser removido do cargo por voto de desconfiança do Parlamento.)

40) Por último, é preciso notar que o Ombudsman é uma instituição com 173 anos de existência, enquanto o nosso Ministério da Desburocratização foi criado há 4 anos. Ou seja, o Ombudsman foi criado pela Constituição sueca de 1809 . Um ano antes, em 1808, a sede do reino português era transferida para o Brasil, dando inicio ao processo de cristalização de um sistema administrativo centralizador, formalista $e$ autoritário

Para finalizar, gostaria de pedir ao Sr. Nilsson que descrevesse o processo de es- 
coitha e eleição do Ombudsman e de perguntar de que maneira ele consegue manter-se acima das injunções politicas ou partidárias da vida parlamentar. 